\title{
EFEKTIVITAS MANAJEMEN LEMBAGA PELATIHAN PT. HANDARU UTAMA NITYASA (HUMANIS GROUP) DI JAKARTA SELATAN
}

\author{
Ahadini Ratri Mayang Sari \\ Said Hutagaol \\ sodoguron_45@yahoo.co.id \\ Hotner Tampubolon \\ hotnertampubolon@yahoo.com
}

\begin{abstract}
Abstrak
Ditengah tekanan kompetisi dalam bidang penyedia layanan pelatihan yang semakin ketat, usaha untuk menjadi lembaga penyedia layanan pelatihan yang dapat memenuhi kebutuhan dan memberikan kepuasan pada klien pengguna jasa bukanlah suatu pekerjaan yang mudah bagi lembaga penyedia layanan pelatihan seperti halnya Humanis Group.Humanis Group diharapkan mampu untuk terus bersaing dengan menunjukkan manajemen yang efektif dalam pengelolaan usaha penyedia jasa pelatihan.Penelitian ini bertujuan untuk mengetahui efektivitas manajemen Humanis Group dalam melaksanakan proses perencanaan, pengorganisasian, pelaksanaan dan pengendalian dalam menjalankan usahanya sebagai lembaga penyedia jasa pelatihan selama kurun waktu tigabelas tahun sehingga mampu bersaing dalam ketatnya persaingan di bidang usaha penyedia jasa pelatihan.Penelitian ini menggunakan metode kualitatif dengan dilakukan melalui teknik sampel dengan pertimbangan tertentu (purposive sampling) melalui wawancara mendalam.Hasil penelitian menunjukkan bahwa manajemen Humanis Group melaksanakan proses perencanaan, pengorganisasian, pelaksanaan dan pengendalian secara efektif dalam menjalankan usahanya, meskipun dalam pelaksanaannya masih terdapat hal-hal yang perlu dioptimalkan dalam fungsi pelaksanaan dan pengendalian.
\end{abstract}

Kata kunci: $\quad$ Efektivitas Manajemen, Lembaga Penyedia Layanan Pelatihan, Fungsi Manajemen. 
Efektivitas Manajemen Lembaga Pelatihan PT. Handaru Vtama Nityasa (Humanis Group) Di Jakarta Selatan

\begin{abstract}
In the middle of competition pressure in the field of training service providers that are increasingly stringent, efforts to become a provider of training services that can meet the needs and provide satisfaction to clients of service users is not an easy job for training service providers such as the Humanis Group. The Humanis Group is expected to be able to continue to compete by showing effective management in managing business training providers. This study aims to determine the effectiveness of the management of the Humanis Group in carrying out the process of planning, organizing, implementing and controlling in conducting its business as a provider of training services for a period of thirteen years so as to be able to compete in the intense competition in the field of training service providers. This study used a qualitative method with a purposivesampling technique which was carried through in-depth interviews. The results showed that the management of the Humanis Group carried out the process of planning, organizing, actuating and controlling effectively in running its business, even though in its implementation there were still things that needed to be addressed in the process of actuating and controlling.
\end{abstract}

Keywords: Effective Management, Training Service Provider, Functions of Management 


\section{A. PENDAHULUAN}

\section{Latar Belakang}

Ditengah tekanan kompetisi dalam bidang penyedia layanan pelatihan yang semakin ketat, baik penyedia layanan pelatihan dari dalam maupun luar negeri, usaha untuk menjadi lembaga penyedia layanan pelatihan yang dapat memenuhi kebutuhan dan memberikan kepuasan pada klien pengguna jasa bukanlah suatu pekerjaan yang mudah.Salah satu lembaga penyedia jasa pelatihan yang memiliki banyak kerjasama dengan berbagai perusahaan lokal maupun multinasional adalah PT. Handaru Utama Nityasa (selanjutnya disebut Humanis Group).

Kemampuan memberi pelayanan terbaik kepada para pengguna jasa menjadi salah satu pertimbangan penguna jasa dalam memilih organisasi yang akan mereka jadikan mitra kerja.Dengan demikian, pengelolaan pelatihan yang dilakukan oleh Humanis Group untuk para pengguna jasa mereka harus dikelola secara efektif dengan manajemen yang baik dan benar untuk mencapai tujuan organisasi.Saat ini, usaha Humanis Group makin berkembang dengan adanya divisi baru maupun semakin banyaknya proyek-proyek yang diterima Humanis Group dengan menjalin kemitraan strategis dengan konsultan luar negeri seperti PwC.

Akan tetapi dalam pelaksanaannya, pimpinan Humanis Groupmenyampaikan hal-hal berikut yang dapat menyebabkan timbulnya permasalahan dalam Humanis Group, yaitu: a) Kegiatan operasional harian Humanis Group masih bergantung dengan peran Managing Partner untuk dapat bersaing dalam merebut peluang yang tersedia dalam pasar penyediaan program pelatihan. Dimana hal ini menyebabkan tergganggunya tugas dan tanggungjawab utama dari Managing Partner Humanis Group dalam membina kemitraan strategis, operational excellence, dan mensejahterakan seluruh stake holder yang ada. b) Adanya kecenderungan dari beberapa pengguna jasa Humanis Group yang menggunakan program pelatihan dari Humanis Group berdasarkan adanya figur yang dikenal memiliki kualitas baik dalam menyelenggarakan pelatihan, dan bukan berdasarkan kualitas Humanis Group secara keseluruhan. C) Adanya perkembangan usaha yang dilakukan Humanis Group, yang membutuhkan penerapan manajemen yang efektif dalam pengelolaan sumber daya uang maupun manusia.

Dengan kondisi tersebut, Humanis Group membutuhkan penerapan manajemen yang efektif melaluiproses perencanaan (planning), pengorganisasian (organizing), pelaksanaan (actuating), dan pengendalian (controlling) dalam pengelolaan sumber daya uang maupun manusia yang lebih luas lagi dengan latar belakang yang beragam. Jika tidak segera mendapat perhatian dari manajemen Humanis Group, maka dikhawatirkan akan memberikan dampak buruk bagi kelangsungan usaha Humanis Group dan menyebabkan Humanis Group akan kalah dalam persaingan dengan para penyedia program pelatihan yang ada. 


\section{Prinsip-Prinsip dalam Manajemen yang Efektif}

Dalam menjalankan organisasi, manajemen yang efektif harus memiliki prinsip-prinsip yang merupakan pedoman umum dalam pelaksanaan aktivitas manajerial, dimana prinsip-prinsip ini digunakan oleh semua sumber daya dalam organisasi. Fayol (1916) dalam Wren, Bedeian \& Breeze (2002:912-918) mengemukakan bahwa untuk mewujudkan manajemen organisasi yang efektif, perlu untuk dilakukan analisis yang cermat dan pengaturan kegiatan manajemen dan manajerial secara tepat yang dilakukan dengan cara: menempatkan tenaga kerja sesuai dengan keahliannya; pengaturan yang jelas mengenai wewenang dan tanggung jawab karyawan dan atasan; kedisiplinan dalam menjalankan pekerjaan; kejelasan mengenai alur datangnya perintah; kesamaan tujuan yang ingin dicapai; mengutamakan kebutuhan organisasi di atas kepentingan pribadi; pengaturan sistem penggajian yang tepat; pemusatan wewenang; pengaturan alur perintah secara jelas dari jabatan tertinggi ke jabatan terendah; keteraturan dalam hal material dan sosial; perlakuan adil dari pemimpin pada bawahan; memberikan dorongan pada karyawan agar selalu memiliki inisiatif; mengembangkan kekompakan dalam bekerjasama di antara para karyawan; menjaga kestabilan karyawan dalam organisasi.

Sebuah perusahaan konsultan McKinsey \& Company pada tahun 1980-an memperkenalkan sebuah alat yang digunakan untuk menganalisis aspek internal organisasi sebuah perusahaan dengan menggunakan 7 (tujuh) elemen utama yaitu: Strategy, Structure, Systems, Share-values, Style, Staff dan Skills (Mandal, 2011:71-76). Model analisis ini kemudian dikenal dengan nama McKinsey's 7-S Framework. Keselarasan ketujuh elemen tersebut dalam organisasi merupakan faktor kunci keberhasilan sebuah perusahaan.

\section{Fungsi-Fungsi dalam Manajemen}

Koontz \& Weihrich (2008) dalam Mandal (2011:130-137) menjelaskan mengenai kegiatan-kegiatan pada proses perencanaan, yaitu: Persepsi tentang adanya peluang, menerapkan maksud atau tujuan, membuat perkiraan, mengidentifikasi alternatif, mengevaluasi alternatif yang tersedia, pilihan dari rencana alternatif, perumusan rencana pendukung, dan menetapkan urutan kegiatan. Hal-hal tersebut dirumuskan Peneliti ke dalam 6 (enam) indikator fungsi perencanaan sebagai berikut: 1) Adanya kesadaran akan peluang yang mungkin terjadi di masa depan. 2) Adanya penerapan visi, misi serta nilai-nilai dalam tujuan usaha di seluruh bagian. 3) Adanya asumsi perencanaan yang bersifat faktual, kebijakan dasar yang berlaku, dan rencana perusahaan yang ada. 4) Adanya alternatif perencanaan yang tersedia untuk mencapai tujuan perusahaan. 5) Adanya perumusan anggaran untuk mendukung berbagai perencanaan. 6) Adanya penetapan urutan kegiatan untuk mencapai rencana kegiatan jangka panjang maupun jangka pendek.

Stoner, Freeman \& Gilbert (1995) dalam Sule \& Saefullah, 2010:152-158) memberikan 4 (empat) dasar untuk melakukan proses pengorganisasian, 
yaitu: pembagian kerja, pengelompokan pekerjaan, penentuan relasi antar bagian dalam organisasi, Koordinasi. Sedangkan Murugesen (2012:6) memberikan beberapa langkah yang perlu untuk digali dan dipertimbangkan untuk dilakukan dalam proses pengorganisasian, yaitu:Memeriksa tujuan organisasi dan tujuan pendukung, kebijakan dan rencana organisasi sesuai dengan yang telah ditetapkan dalam tahap perencanaan, mengidentifikasi kegiatan, proses dan keterampilan yang diperlukan untuk mencapai tujuan dan sasaran dalam kerangka kebijakan yang ditetapkan oleh organisasi, mengelompokkan dan mengklasifikasikan kegiatan berdasarkan sumber daya dan keterampilan baik manusia dan non-manusia yang tersedia, mendelegasikan wewenang dan tanggung jawab kepada kepala masing-masing kelompok untuk kinerja, menyatukan kelompok-kelompok.Hal-hal tersebut dirumuskan Peneliti ke dalam 3 (tiga) indikator fungsi pengorganisasiansebagai berikut:1) Adanya pengelompokkan dan klasifikasikan kegiatan berdasarkan sumber daya yang tersedia. 2) Adanya pendelegasikan wewenang dan tanggung jawab kepada masing-masing unit kerja dan relasi antar bagian/hirarki yang jelas dalam struktur organisasi. 3) Adanya kerjasama antara berbagai bagian dalam organisasi dalam menjalankan fungsinya masing-masing untuk mencapai tujuan organisasi.

Cannice, Koontz \& Weihrich (2013:544-547) memberikan prinsip-prinsip yang perlu untuk diikuti agar fungsi pelaksanaan dalam manajemen dapat efektif, yaitu adanya kontribusi yang maksimal dari individu, adanya tujuan yang harmonis, adanya kesatuan komando, adanya teknik pengarahan yang tepat, adanya komunikasi manajerial, digunakannya organisasi informal dalam menyampaikan informasi, adanya kepemimpinan yang baik untuk mempengaruhi bawahan dan membuat mereka bekerja sesuai dengan keinginan mereka, dan mamnjemen dapat memantausejauh mana kebijakan, prosedur, dan instruksi diikuti oleh bawahan.Hal-hal tersebut dirumuskan Peneliti ke dalam 5 (lima) indikator fungsi pelaksanaan sebagai berikut:1) Adanya kejelasan mengenai kebijakan-kebijakan yang diterapkan oleh pimpinan dalam mencapai tujuan perusahaan kepada seluruh karyawan yang ada. 2) Adanya kejelasan mengenai kebijakan-kebijakan yang diterapkan oleh pimpinan dalam mencapai tujuan perusahaan kepada seluruh karyawan yang ada. 3) Adanya motivasi dari manajemen agar karyawan memberikan kontribusi secara optimal dan melakukan perencanaan secara berkesinambungan untuk mencapai tujuan perusahaan. 4) Adanya kemampuan karyawan dalam bekerja dengan mengikuti standar prosedur yang ditetapkan. 5) Adanya sistem penghargaan maupun teguran yang diterapkan oleh manajemen bagi para karyawan.

Benowitz (2001: 274-275) memberikan empat langkah utama dalam proses pengendalian, dimana langkah-langkah tersebut harus diulangi secara berkala sampai tujuan organisasi tercapai. Empat langkah yang harus dilakukan dalam proses pengendalian yaitu: Menetapkan standar untuk mengukur kinerja, mengukur kinerja aktual, membandingkan kinerja dengan standar yang telah ditetapkan, mengambil tindakan korektif. Hal-hal tersebut dirumuskan Peneliti ke dalam 4 (empat) 
indikator fungsi pengendalian sebagai berikut: 1) Adanya standar kinerja spesifik yang ditetapkan manajemen dalam mengukur kinerja. 2)Adanya sistem umpan balik yang dirancang dengan baik. 3) Adanya pengukuran kinerja secara faktual. 4) Adanya proses evaluasi untuk dapat dilakukan perbandingan antara kinerja yang aktual dengan standar yang telah ditetapkan. 5) Adanya tindakan korektif yang diambil jika terjadi penyimpangan dalam organisasi.

\section{B. METODE PENELITIAN}

Penelitian ini dilakukan dengan pendekatan penelitian kualitatif dan merupakan jenis penelitian deskriptif Achmadi \& Narbuko (2005:44) menyatakan penelitian deskriptif sebagai penelitian yang berusaha menuturkan pemecahan masalah yang ada berdasarkan data, menyajikan data, menganalisis, hingga menginterpretasi. Penelitian deskriptif juga dilakukan untuk memberikan gambaran yang lebih detail mengenai suatu gejala atau fenomena, serta bertujuan untuk menggambarkan mekanisme sebuah proses (Prasetyo \& Jannah, 2005:42-43). Penelitian deskriptif juga tidak bertujuan untuk menguji hipotesis, karena sifat dari penelitian ini hanya menggambarkan saja (Zulganef, 2018:71). Pemilihan sample narasumber/informan dalam wawancara mendalam dilakukan melalui teknik sampel tujuan khusus (purposeful sampling). Menurut Cresswell (2008: 214) teknik sampel tujuan khusus (purposeful sampling) adalah "pemilihan partisipan secara sengaja oleh peneliti, atas dasar kualitas, pengalaman, dan pengetahuan yang dimiliki partisipan. "Narasumber dalam penelitian ini berjumlah 3 orang dan merupakan karyawan Humanis Group dengan posisi Managing Partner, Senior Consultant, dan karyawan bagian administrasi.

Teknik analisis data yang digunakan dalam penelitian kualitatif mencakup transkip hasil wawancara, reduksi data, analisis, interpretasi data dan triangulasi Dari hasil analisis data yang kemudian dapat ditarik kesimpulan.

\section{HASIL PENELITIAN DAN PEMBAHASAN}

\section{Fungsi Perencanaan}

Manajemen Humanis Group memiliki kesadaran untuk senantiasa mengikuti arus perkembangan di masyarakat dan berusaha menciptakan peluang bagi perusahaan untuk dapat mencapai tujuannya dengan mengembangkan usaha baru dalam bidang riset dan juga sistem monitoring dan evaluasi dengan mengandalkan kekuatan teknologi online. Manajemen Humanis Group telah menerapkan tata nilai perusahaan yaitu professionalism, agility, creative, integrity dalam perencanaan program dan pelayanan terhadap klien, proses memperoleh pekerjaan, dan perencanaan pengembangan usaha.

Manajemen Humanis Group telah membuat perencanaan yang faktual dalam perencanaan tahunan perusahaan, perencanaan proyek, perencanaan pembiayaan, namun masih membutuhkan perencanaan yang lebih baik untuk perencanaan content development.

Manajemen Humanis Group telah membuat alternatif perencanaan dan senantiasa melakukan evaluasi untuk mengantisipasi terjadinya kesalahan, 
selain itu juga dilakukan proses penyesuaian untuk mencapai tujuan perusahaan.

Manajemen Humanis Group telah membuat perumusan anggaran yang mendukung berbagai perencanaan perusahaan maupun proyek-proyek yang dilakukan dengan melibatkan peran controller agar marjin keuntungan yang diinginkan perusahaan dapat terpenuhi. Manajemen Humanis Group telah membuat perencanaan secara rinci dengan membuat alur bisnis yang jelas dimana dalam tahapan project preparation memberikan informasi yang rinci mengenai alokasi sumber daya yang terlibat dalam proyek yang ditangani Humanis Group.

\section{Fungsi Pengorganisasian}

Manajemen Humanis Group telah melakukan pengelompokan dan klasifikasi kegiatan berdasarkan sumber daya yang mereka miliki, yaitu Divisi POD, Divisi McD dan Divisi Aha.

Manajemen Humanis Group melakukan pendelegasian wewenang dan tanggungjawab kepada masing-masing unit kerja dan memiliki hirarki yang jelas dalam struktur organisasi, walupun tekadang masih terdapat pengabaian oleh pimpinan perusahaan dalam pendelegasian tugas, namun sifatnya ringan.

Terdapat kerjasama dan koordinasi dari masing-masing bagian di dalam Humanis Group, walaupun masih terjadi friksi-friksi ringan di antara para Project Manager, namun hal tersebut masih dapat diatasi dan ditemukan penyelesaian masalahnya.

\section{Fungsi Pelaksanaan}

Terdapat penjelasan dari pemimpin mengenai kebijakan-kebijakan yang diterapkan di Humanis Group kepada seluruh karyawan yang ada Manajemen Humanis Group juga memberikan motivasi bagi karyawan agar dapat memberikan kontribusi secara optimal dan melakukan perencanaan secara berkesinambungan untuk mencapai tujuan perusahaan. Namun, karyawan Humanis Group dinilai masih belum dapat memberikan kontribusi secara optimal maupun melakukan perencanaan secara berkesinambungan.

Karyawan Humanis Group belum memiliki kemampuan untuk bekerja sesuai standar prosedur, dan masih tergantung dengan kemampuan atasan dalam melibatkan tim nya untuk bekerja sesuai dengan standar prosedur. Manajemen Humanis Group memberlakukan sistem penghargaan bagai karyawan dengan kenaikan gaji, insentif, dan bonus. Dan memberlakukan teguran bagi para karyawan dengan pemberian teguran secara verbal, Surat Peringatan, maupun pemotongan bonus.

\section{Fungsi Pengendalian}

Manajemen Humanis Group tidak memiliki standar kinerja yang jelas bagi para karyawannya.

Manajemen Humanis Group memiliki sistem umpan balik berupa sistem survey maupun lembar survey yang digunakan untuk proyek-proyek yang sedang ditangani maupun untuk karyawannya. Walaupun manajemen 
Humanis Group tidak memiliki sistem pengukuran kinerja, dan melakukan pengukuran berdasarkan penilaian pribadi dari Managing Partner dalam hal pemberian penghargaan berupa bonus.

Manajemen Humanis Group melakukan proses evaluasi terhadap karyawan maupun proyek-proyek yang sedang ditangani melalui program Dekorasi dan pertemuan rutin mingguan.

Manajemen Humanis Group melakukan tindakan korektif dengan cara memberikan teguran, pemberian Surat Peringatan hingga pemutusan hubungan kerja.

\section{KESIMPULAN, IMPLIKASI, DAN SARAN}

\section{Kesimpulan}

Humanis Group sebagai lembaga penyedia jasa pelatihan dapat dikatakan memiliki efektivitas yang baik dalam menjalankan usahanya selama 13 tahun ini.Humanis Group menunjukkan efektivitas yang baik dalam menjalankan fungsi perencanaan (planning) di dalam manajemen usahanya, yang dapat terlihat melalui:Nilai-nilai perusahaan yang menjiwai seluruh kegiatan dalam menjalankan usaha, perencanaan yang dapat dilaksanakan oleh karyawannya, dimana telah dibuat alur yang jelas dalam usaha untuk mendapatkan pekerjaan, perencanaan tahunan perusahaan, perencanaan proyek, dan perencanaan pembiayaan sudah dirancang dengan baik, Adanya kejelasan mengenai sumber daya yang dibutuhkan agar perencanaan dapat terlaksana, dan manajemen enantiasa melakukan evaluasi terhadap perencanaan yang dibuat agar dapat mengantisipasi masalah yang mungkin timbul dan kemudian menemukan alternatif bagi perencanaan tersebut.

Humanis Group menunjukkan efektivitas yang baik dalam menjalankan fungsi pengorganisasian (organizing) sebagai usaha untuk menyelaraskan perencanaan yang dibuat dengan apa yang nantinya akan dilaksanakan, yang dapat terlihat melalui koordinasi yang baik antar divisi, dan melakukan pengelompokan dan klasifikasi kegiatan berdasarkan sumber daya yang mereka miliki, yaitu Divisi POD, Divisi McD dan Divisi Aha.

Humanis Group belum menunjukkan efektivitas yang optimal dalam menjalankan fungsi pelaksanaan (actuating) di dalam manajemen usahanya, yang dapat terlihat melalui belum mampunya karyawan memberikan kontribusi secara optimal maupun menjalankan rencana secara berkesinambungan tanpa adanya motivasi atau ketergantungan terhadap pemimpin.

Humanis Group belum menunjukkan efektivitas yang optimal dalam menjalankan fungsi pengendalian (controlling), di dalam manajemen usahanya, yang dapat terlihat melalui belum adanya standar kinerja dan sistem pengukuran kinerja yang obyektif yang diterapkan.

\section{Implikasi}

Berdasarkan temuan hasil penelitian yang ada, berikut adalah beberapa dampak atau akibat langsung dari temuan hasil penelitian, dan perkiraan ke depan serta perumusan tindakan yang dapat dilakukan: 
- Dalam fungsi perencanaan, manajemen Humanis Group perlu mengembangkan perencanaan yang lebih baik dalam proses pengembangan modul-modul pelatihan yang ada, sehingga modulmodul yang diberikan dapat lebih sesuai dan tepat sasaran sesuai dengan kebutuhan pengguna jasa pelatihan Humanis Group.

- Dalam fungsi pengorganisasian, terdapat 2 (dua) hal yang dapat memberikan dampak bagi Humanis Group, yaitu:

- Managing Partner perlu untuk melakukan pendelegasian tugastugas ringan untuk dilakukan para karyawan yang ada di bawahnya, sehingga tidak mengganggu tugas-tugas utama Managing Partner dalam membina kemitraan strategis maupun mensejahterahkan seluruh Stake holder yang ada.

- Manajemen Humanis Group perlu membuat sistem pengaturan dalam penggunaan sumber daya dan fasilitas perusahaan yang ada maupun menambah fasilitas atau logistik yang diperlukan saat Humanis Group menerima beberapa pekerjaan yang terjadi di waktu yang bersamaan, sehingga dapat mengurangi friksi-friksi yang terjadi di antara para Project Manager.

- Dalam fungsi pelaksanaan, terdapat 2 (dua) hal yang dapat memberikan dampak bagi Humanis Group, yaitu:

- Manajemen Humanis Group perlu membuat prosedur pelaksanaan pekerjaan secara terstandarisasi, sehingga dapat diikuti semua karyawan tanpa perlu adanya intervensi secara intensif dari atasan dan meningkatkan kemampuan karyawan untuk dapat bekerja sesuai dengan standar yang diharapkan oleh manajemen Humanis Group.

- Manajemen Humanis Group perlu menegakkan aturan yang jelas disertai pemberian sanksi yang berlaku secara obyektif, sehingga dapat meningkatkan kedisiplinan karyawan dalam hal kehadiran.

- Dalam fungsi pengendalian, manajemen Humanis Group perlu untuk merumuskan pengukuran kinerja dengan jelas bagi karyawan, termasuk dalam sistem perhitungan bonussehinggadapat menghindari timbulnya ketidakpuasan pada para karyawan.

\section{Saran}

Berdasarkan kesimpulan dari hasil penelitian yang sudah dilakukan, Peneliti memiliki sejumlah saran untuk meningkatkan efektifitas Humanis Group dalam melaksanakan fungsi-fungsi manajemen dalam mencapai tujuan yang direncanakan. Berikut adalah saran Peneliti:

1. Mempertahankan efektivitas manajemen Humanis Group yang sudah baik dalam fungsi perencanaan, pengorganisasian, pelaksanaan dan pengendalian.

2. Meningkatkan efektivitas manajemen Humanis Group secara lebih optimal lagi dalam fungsi pelaksanaan dan pengendalian, melalui:

- Memberikan pelatihan yang berkaitan dengan pengembangan diri ataupun peningkatan kemampuan atau keterampilan bagi karyawan-karyawan permanen yang dinilai memiliki kemampuan 
rendah dalam bekerja sesuai dengan standar yang diharapkan oleh perusahaan.

Manajemen Humanis Group dapat memberikan pelatihan yang bersifat teknis bagi karyawannya, dimana memungkinkan karyawan untuk melakukan pekerjaan, tugas dan tanggungjawab dengan baik. Contoh pelatihan ini adalah pelatihan tentang proses dan prosedur teknis dan hubungan pelanggan.

Manajemen dapat juga memberikan pelatihan yang bersifat pemecahan masalah dan pelatihan antar pribadi. Tujuan dari pelatihan yang diberikan ini adalah agar karyawan dapat mengatasi masalah operasional dan antarpribadi serta meningkatkan hubungan dalam pekerjaan organisasional, seperti komunikasi anatr pribadi, keterampilan manajerial atau kepengawasan, maupun pemecahan konflik. Contoh dari pelatihan ini adalah pelatihan Project Management ataupun pelatihan Communication Skills.

- Memberlakukan sistem rekrutmen yang lebih baik lagi bagi karyawan baru maupun karyawan lepas (associates) yang terlibat dalam proyek-proyek yang ditangani Humanis Group.

- Merumuskan standar kinerja dan sistem pengukuran kinerja bagi karyawan Humanis Group agar sistem imbalan maupun teguran yang diterapkan bagi karyawan menjadi lebih transparan dan obyektif.

Manajemen Humanis Group dapat melakukan sistem pengukuran kinerja dengan memperhatikan dimensi berikut ini, yaitu: kuantitas pekerjaan yang dihasilkan karyawan dalam kurun waktu tertentu, kualitas pekerjaan dalam menangani tugas yang diberikan, kemandirian dalam mengerjakan tugas yang diberikan, inisiatif dalam menerima tanggung jawab, kemampuan karyawan untuk beradaptasi, dan kemampuan karyawan dalam bekerjasama dalam mencapai tujaun perusahaan.

3. Mengadakan penelitian lanjutan mengenai efektivitas manajemen Humanis Group yang melibatkan seluruh karyawan baik karyawan permanaen maupun karyawan lepas (associates) dari berbagai tingkatan jabatan, agar mendapatkan gambaran yang lebih mendalam.

\section{DAFTAR PUSTAKA}

Achmadi, A., Narbuko, C. (2005). Metodologi Penelitian. Jakarta: PT Bumi Aksara.

Adeniyi, M. A (2007). Effective Leadership Management: An Integration of Styles, Skills \& Character for Today's CEOs. Indiana: AuthorHouse.

Azwar.(1996). Pengantar Administrasi Kesehatan Edisi Ketiga.Jakarta : Binarupa Aksara.

Benowitz, E.A. (2001). CliffsQuickReview:Principles of Management. New York: Wiley Publishing, Inc.

Creswell, J. W. (2008). Educational Research Planning, Conducting and Evaluating Quantitative and Qualitative Research (Third ed.). New Jersey 07458, USA: Pearson Education, Inc. 
Daft, R.L., (2010). New Era of Management. 9th Edition, International Edition,. Boston: CENGAGE Learning.

Etikan, I., Musa, S. A., \& Alkassim, R. S. (2016).Comparison of Convenience Sampling and Purposive Sampling. American Journal of Theoretical and Applied Statistics, 5, 1-4. https://doi.org/10.11648/j.ajtas.

Fauzi., Irviani, R. (2018). Pengantar Manajemen. Edisi Revisi. Yogyakarta: Andi Offset

Haimann, T., Scott, W.G., Connor, P.E. (1982).Houghton Miflin C International Inc

Hamali, A.Y., Budihastuti, E.S. (2019). Pemahaman Praktis Administrasi, Organisasi dan Manajemen:Strategi Mengelola Kelangsungan Hidup Organisasi. Jakarta: Prenadamedia Group.

Hanafi.(2003). Manajemen Cetakan kedua. Yogyakarta: Unit Penerbit dan Percetakan Akademi Manajemen Perusahaan.

Indrawan, R., \& Yaniawati, P. (2014). Metodologi Penelitian Kuantitatif, Kualitatif, dan Campuran untuk Manajemen, Pembangunan, dan Pendidikan. Bandung: PT Refika Aditama.

Mandal, S.K. (2011). Management: Principles and Practice. Mumbai: Jaico Publishing House

Manulang, M. (2012).Dasar-Dasar Manajemen. Jakarta: Ghalia Indonesia

Milles, M.B., Huberman, M.A. (1984). Qualitative Data Analysis. London:SAGE Publications

Moleong, L.J. (2016).Metodologi Penelitian Kualitatif, Edisi Revisi. Bandung: Remaja Rosdakarya

Murugesan, G. (2012). Principles of Management. New Delhi: University Science Press.

Nurzaman, K. (2014). Manajemen Perusahaan. Jakarta: Pustaka Setia

Patton, M.Q. (1990). Qualitative Evaluation Methods. Beverly Hills: SAGE Publications

Prasetyo, B., \& Jannah, L. M. (2005). Metode Penelitian Kuantitatif. Jakarta: PT RajaGrafindo Persada

Putra, N. (2011). Penelitian Kualitatif: Proses dan Aplikasi. Jakarta: Indeks . (2013). Metode Penelitian Kualitatif Manajemen. Jakarta: Rajawali Press

Reddin, W.J. (1970), Managerial Effectiveness, New York: McGraw-Hill

Robbins, S.P., Coulter, M. (2012). Management: $11^{\text {th }}$ edition. New Jersey: Prentice Hall

Silalahi, U (2011). Studi Tentang Ilmu Administrasi: Konsep, Teori dan Dimensi. Cetakan ke Sembilan. Bandung: Sinar Baru Algesindo

Siswanto.(2007). Pengantar Manajemen. Jakarta: PT. Bumi Aksara.

Sukarna.(2011). Dasar-Dasar Manajemen. Bandung: Mandar Maju

Sule, E.T., Saefullah, K. (2010). Pengantar Manajemen.Cetakan ke 5. Jakarta: Kencana-Prenada Media Grup.

Thietart, R. (2001). Doing Management Research: A Comprehensive Guide. London: SAGE Publications

Tripathi, P.C \& Reddy, P.N. (2008).Principles of Management 4th edition. New Delhi: Tata McGraw-Hill Publishing Company Limited. 
Efektivitas Manajemen Lembaga Pelatifan PT. Handaru Vtama Nityasa (Humanis Group) Di Jakarta Selatan

Wren, D.A., Bedeian, A.G., Breeze,J.D. (2002). The foundations of Henri Fayol's Administrative Theory.Management Decision 40/9 [2002] 906 \pm 918 . http://bus.lsu.edu/management/faculty/abedeian/articles/Fayol.pdf Zulganef.(2018). Metode Penelitian Bisnis dan Manajemen. Bandung: Refika Aditama 